BYLAE : KOERS, APRIL 1961.

\title{
VERWANTSKAPSBEPALING IN DIE DIERKUNDE
}

(Inougurele Rede gelewer by die aanvaarding van die Professoraat in Dierkunde aan die Potchefstroomse Universiteit vir C.H.O. op Vrydag 21 April 1961).

Hooggeleerde Rektor van die Potchefstroomse Universiteit vir C.H.O., Hooggeagte here lede van die Raad van hierdie Universiteit, Hooggeleerde here Professore, Dames en here Lektore,

Dames en here Studente,

Dames en Here,

Dit is ' $n$ voorveronderstelling van alle natuurwetenskaplike navorsing dat die natuur, waarvan die mens ook 'n deel uitmaak, nie 'n chaos nie maar 'n ordelike geheel is. Hierdie ordelikheid word nie deur die mens in die natuur ingedra nie maar kan slegs broksgewys deur waarneming en navorsing uit die natuur geabstraheer word.

\section{Eendersheid as basis van klassifikasie}

Die eerste stap in die ontleding van enige vorm van kennis is om die waargenome verskynsels in 'n ordelike sisteem te klassifiseer en daarom verbaas dit niemand dat die taksonomie of sistematiek, d.w.s. die klassifikasie van die organismeryk, die oudste dissipline in die Biologie is nie. Die mens het immers van die begin af name gegee aan die diere en plante aan hom bekend. Selfs die Skrif bied in Genesis I 'n elementêre klassifikasie van die organismeryk wanneer $\mathrm{Hy}$ van die volgende groepe melding maak: Grasspruitjies, struike, plante wat saad gee, bome wat vrugte dra waarin hulle saad is, lewende wesens wat groei, visse van die see, groot seediere, kruipende diere, voëls, wilde diere van die veld, vee en mense. Die hasis van hierdie klassifikasie is eendersheid of gelykagtigheid t.o.v. morfologie, habitat, voortplanting, etologie en fisiologie.

Hierdie beginsel van eendersheid en verskillendheid is sedert die vroegste tye deur die natuurondersoekers in die klassifikasie van die organismeryk ingedra, om geen ander rede nie as om, met behulp daarvan, uitdrukking te gee aan die ordelik. heid en die anatomiese verwantskappe wat daar binne die organismeryk bestaan sonder om daarmee iets aangaande hulle oorsprong te kenne te gee. As hierdie ordening reeds in die dae van Aristoteles nodig was dan is dit in ons dag nood. saaklik as ons bedink dat daar tans, na skatting, reeds meer as 2,000,000 dierspesies bekend is en dat nuwes aan die wetenskap bekend gestel word teen 'n tempo van ongeveer 10,000 per jaar.

Sover dit die organismes betref wat saam gegroepeer word, val die klem op eendersheid terwyl by dié wat in verskillende groepe geplaas word dit die verskille is wat beklemtoon word. Die taksonoom moet hom begeef in die meerderheid van die fundamentele probleme van die Biologie soos die beheer van liggaamsvorm, 
groeipatrone, ekologiese reaksies, aanpassing, reguleringsmeganismes, etologie, meganismes van oorerwing en nog meer. Die vergelykende morfologie was egter van die begin af, is vandag nog en $s . I$ in die toekoms ook die ruggraat van alle taksonomiese navorsing bly. Van die museumkurator en paleontoloog kan immers nie verwag word dat hulle hul gepreserveerde en versteende versamelings moet rangskik volgens hulle chromosoomgetalle, serumagglutinasies of paringsgedrag nie en dit om die eenvoudige rede dat hierdie bestansaspekte van die organismes nie vir hulle toeganklik is nie.

Dit het egter gou duidelik geword dat dit nie altyd maklik is om die beginsel van eendersheid in die taksonomie toe te pas nie omdat oppervlakkig eenderse organismes dikwels meer wesensverskillend as oppervlakkig nie-eenderse organismes is. Die volgende voorbeeld sal dit illustreer: Die Australiese mieregel, Echidna, sowel as die Suid-Afrikaanse ystervark, Hystrix, en krimpvarkie, Erinaceus, besit 'n huidbedekking van stewige penne wat 'n opvallende uitwendige gelykagtigheid meebring. Ten spyte hiervan word Echidna onder die Monotremata geklassifiseer, Erinaceus onder die Insectivora en Hystrix onder die Rodentia. Elkeen van hierdie drie vertoon nl. in sekere opsigte gelykagtigheid met ander diere wat van groter taksonomiese belang is as hulle gelykagtigheid aan mekaar. Uit die Dierkunde alleen kan 'n oneindige reeks van soortgelyke voorbeelde aangehaal word.

\section{Homologie}

Uit hierdie en soortgelyke ervarings is gebore die opvatting dat alleen daardie soort eendersheid wat op homologie herus 'n betroubare maatstaf vir die klassifikasie van organismes daarstel en in 1843 is die homologiebegrip dan ook vir die eerste maal deur Owen op 'n duidelike wyse gedefinieer as "the same organ in different animals under every variety of form and function". Volgens hierdie maatstaf moet die voorbeen van 'n perd, die vlerk van 'n voël en die arm van 'n aap as homoloë strukture beskou word en op grond daarvan word hulle saam onder die Tetrapoda gegroepeer.

Owen se opvattings aangaande homologie het niks te doen gehad met die evolusiegedagte wat reeds gedurende die 18e eeu goed gevestig geraak het nie. Soos sy tydgenote was hy, skeptikus wat hy was, slegs op soek na 'n gemeenskaplike houplan vir die werweldiere sonder om 'n oorsaak te probeer vind vir die bestaan van 'n sodanige bouplan. Dit het by hom gegaan alleen om die bepaling van anatomiese verwantskap.

Die groot veldslag ten gunste van die evolusiegedagte het tot die $19 \mathrm{e}$ eeu uitgelly toe Charles Darwin met sy boek "On the origin of species by means of natural selection" (1859) tegelykertyd die bekendste en mees besproke bioloog van alle tye geword het. 


\section{Homologie en Filogenie}

Sewe jaar later, in 1866, het Haeckel die Darwinse teorie van evolusie in die vergelykende anatomie ingevoer en tot die slotsom geraak dat die besit van homoloë strukture deur twee of meer organismes op 'n gemeenskaplike voorvader vir daardie organismes dui. Hiermee het Haeckel anatomiese verwantskap tot kriterium van filogenetiese verwantskap verhef. Hierdie postulaat het nie alleen 'n magtige stimulus vir die vergelykende anatomie geword nie maar het ook verreikende gevolge gehad, want nou het die filogenetici nie slegs begin om alstammingsverhoudings uit dic klassifikasiestelsels, wat ewe-eens op die beginsel van homologie gebaseer is, af te lei nie maar hulle kon ook na willekeur stambome opstel. Dit was en is nog 'n gevaarlike praktyk want die sistematiek kan nooit die geskiedenis van die lewe in meer as hoogstens breë trekke ontrafel nie en gee ook nie voor om meer as dit te doen nie.

Probleme i.v.m. Homologie as Filogenetiese argument

Die byna koorsagtige gesoek na homologieë met die doel om daarmee afstammingsverhoudings op te spoor het spoedig talryke slaggate openbaar wat nie alleen deur die filogenetici vermy moet word nie maar wat ook 'n belangrike vraagteken bokant die betrouhaarheid van hierdie uitgangspunt plaas. Gegenbaur het trouens in 1878 reeds gewaarsku dat bloedverwantskap twyfelagtig word in dieselfde mate as wat die bewyse vir homologie twyfelagtig word.

Vergun my dus om 'n paar van die probleme in verband met die toepassing van die beginsel van homologie met $u$ te bespreek want as die basiese leerstellings van 'n wetenskap onder verdenking kan kom dan is dit die eerste taak van daardie wetenskap om die betrokke leerstellings krities te ondersoek.

\section{Ondefinieerbaarheid van die begrip}

As dit waar is dat homologie as maatstaf van filogenetiese verwantskapsbepaling gebruik mag word dan moet daar een of ander kriterium bestaan vir die herkenning daarvan. Die besprekings van De Beer (1938, 1958), Boyden (1943), Szarski (1949), Maslin (1952), Dice (1952), Bigelow (1958, 1959), Kiriakoff (1959) en Greenberg (1959) laat aan die leser geen ander keuse as om met dic volgende uitspraak van Szarski saam te stem nie: 'n Ondersoek van die huidige status van die homologiebegrip lei tot die verontrustende gevolgtrekking dat 'n basiese term van een van die belangrikste soölogiese wetenskappe, t.w. vergelykende anatomie, nie volkome bevredigend gedefinieer kan word nie.

Uit die talle definisies wat sedert die tyd van Owen van tyd tot tyd voorgestel is, stel Boyden (1947, aangehaal uit Szarski) die volgende definisie saam: Homolö strukture is essensieel gelykagtig in struktuur en embrioniese ontwikkeling en in hulle relatiewe posisies en hulle verhoudings tot ooreenstemmende dele van die liggame van organismes. Behalwe die tradisionele vereiste van gelykagtigheid t.o.v. volwasse struktuur en relatiewe posisie in die liggaam wat reeds deur Owen gestel 
is, mort homolö̈ strukture dus ook nog essensieel gelykagtig wees t.o.v. hulle embrioniese ontwikkeling.

Wat leer die werklikheid ons in hierdie verband? Laat ons dit ondersoek aan die hand van organe of strukture soos die timusklier, neusgange en sakraalwerwels wat tradisioncel as homoloog met die ooreenstemmende strukture by ander diere aanvaar word.

1) Terwyl die limusklier by honde en beeste uit die ektoderm ontwikkel is dit hy die vark, muis en marmoljie van beide ekto- en endodermale oorsprong. Homologie kan dus nie in alle gevalle tot dieselfde moederweefsel teruggevoer word soos die bostaande definisie vereis nie.

2) Die neusgange van die Tetrapoda deurloop nie dieselfde ontwikkelings. proses nie, want terwyl dit by die paddas en salamanders ontstaan as blinde sakkies wat steeds dieper word totdat dit in die mondholte deurbreek, ontstaan dit hy alle ander Tetrapoda, insluitende die Gymnophiona, as 'n oop groef wat later tot 'n buis omvorm word deur weefsel wat van die mediane kant af oor die groef groei. Dit voldoen dus ook nie aan die definisie se voorwaarde vir homoloë strukture nie.

3) Die sakraalwerwel waaraan die hekkengordel vasgeheg word ontwikkel by sommige Amphibia (Rana) uit die 9e en by ander (Cryptobranchus) uit die 20e metameer. Volgens heide Gegenhaur (1870) en Boyden (1947) se definisies kan die sakraalwerwels van Rana en C.ryptobranchus dus nie homoloog wees nie.

laat ons nog dieper in die prohleem indring. Dit is welbekend dat die ontwikkeling van ' $n$ bepaalde orgaan afhanklik is nie slegs van 'n spesifieke moederweefsel nie maar ook van die invloed wat deur die omringende weefsel, bekend as die induserende weefsel, daarop uitgeoefen word. As, byvoorbeeld, 'n stukkie van die buikepidermis van 'n paddaembrio op die mondgebied van 'n urodeelembrio oorgeplant word, verloor dit sy karakter as buikepidermis en ontwikkel tot mondepidermis en lippe. Dit gee egter ook oorsprong aan horingtandjies en suiers, leide waarvan by geen normale urodeelembrio alangetref word nie. Die mondgelied induseer dus die buikepidermis om hom soos mondepidermis te gedra maar die paddaepidermis behou sy potensialiteit om horingtandjies en suiers te produseer wat aan die urodeel vreemd is.

Uit hierdie en ander eksperimente van soortgelyke aard kan twee gevolgtrekkings gemaak word. Ten eerste wil dit voorkom asof, binne elke diergroep, beide die induserende en reagerende weefsel aktief beheer uitoefen oor die soort orgaan of struktuur wat gevorm word. Ten Iweede kan afgelei word dat, by die ontstaan van homoloë strukture, dit nie noodwendig so is dat óf die induseerders óf die reagerende weefsel homoloog sal wees nie. Met ander woorde die ooreenkomste tussen homoloë strukture hy twee organismes kan nie, soos volgens die definisie verwag kan word, teruggevoer word tot selle wat gelykwaardige posisies in die twee embrios inneem nie of tot gelykwaardige dele van die cier waaruit die struktuur ontwikkel nie en ook nie tot gelykwaardige ontwikkelingsmeganismes nie. Inteendeel. 
Teenoor die hogenoemde opvatting van wat homologie is staan dié van Haeckel (1866), Gegenbaur (1870), Lankester (1870), De Beer $(1938,1958)$ en andere waarvolgens twee eenderse strukture met mekaar homoloog is wanneer hulle, hoe gewysigd ookal, deur afstamming, van 'n soortgelyke struktuur in die gemeenskaplike voorvader tot stand gekom het.

Die kritick op hierdie uitgangspunt lê voor die hand want hiermee word die har voor die perd gespan. Eers moet hewys worl dat twee organe deur oorerwing van 'n gemeenskaplike voorvader afgestam het voordat besluit kan word dat hulle homoloog is. Die besit van die twee organe hewys dus op sigself geen verwantskap nie maar is die resultaat daarvan.

\section{IIomologiee en parallelisme'}

Naas die ondefinieerlaarheid van die homologiebegrip is daar 'n tweede struikelblok in die weg van verwantskapshepaling op grond van morfologiese gelykagtigheid. Dit is die omstandigheid dat nie alle gevalle van eendersheid op homologie teruggevoer kan word nie want eendersheid kan ook deur parallelle ontwikkeling en deur variasie tot stand kom, in welke gevalle dit nie noodwendig verwantskap aandui nie.

Parallelisme, soos deur Romer gedefinieer, is daardie verskynsel waarby twee of meer diervorme, hasies cenders in houvorm en verwant aan mekaar, gemeenskaplike kenmerke hesit wat by hulle gemeenskaplike voorvader ontbreek het en wat hulle dus alhei op onafhanklike wyse ontwikkel het. As voorbeeld geld bv. die vingerhegskyfies wat by die Loombewonende genera binne die families Bufonidae, Dendrobatidae, Hylidae, Ranidae, Polypedatidae en Brevicipitidae onder die Anura aangetref word maar by die nie-boombewonende genera van dieselfde families afwesig is. Dit word dikwels verwar met konvergensie waarlyy twee vorme wat van radikaal verskillende voorvaders met hasies verskillende bouplanne afkomstig is, cenderse strukture besit wat 'n uitdruklike aanpassing aan eenderse bestaanseise is. So bv. kan die swemvliese tussen die tone van eende, paddas, bewers ens. nie as 'n erfenis van verwante voorvaders beskou word nie.

Feitlik alle paleontoloë beklemtoon die menigvuldigheid van parallelle ontwikkeling in die diereryk. Romer (19.19) beweer dat die bekende en so baie verdagte gevalle van parallelisme suggercer dat dit 'n hyna universele verskynsel kon gewees het.

Die algemeen aanvaarde kernverskil tussen parallelisme en homologie is die volgende. By homologie moes die strukture of organe wat by die nakomelinge aangetref word ook by die gemeenskaplike voorvader aanwesig gewees het terwyl dit, in die geval van parallelisme, nie by die gemeenskaplike voorvader teruggevind kan word nie. In 1932 verklaar Huxley egter dat die manifestasie van 'n eienskap in die voorouer, om ontwikkelingsredes versluier of vertraag kon gewees het om dan later, by verwante, hoewel divergerende, stamme, skynhaar onafhanklik van mekaar as feillik gelykwaardige eienskappe tot sigbare ontwikkeling te kom. Hierdie verskynsel beskryf De Beer as "latente homologie" sodat die betrokke strukture dan tog verwantskapshepalende waarde sou besit. 
Hierdie uitleg het die probleem om tussen homologie en parallelisme te onderskei slegs tydelik uitgeskakel want in 1945 suggereer Huxley dat parallelisme ook nog op twee alternatiewe moontlike wyses tot stand mag kom, t.w. i) deur oneenderse mutasies van dieselfde geen wat nogtans, gedurende die ontogenie, tot eenderse strukture mag ontwikkel en ii) as struktuurgelykvormighede wat beide gedurende die filogenie en die ontogenie deur verskillende faktore bewerkstellig word. Huxley gee self toe dat die laasgenoemde geval nie homologie kan wees nie, sodat dit nou nodig word om te onderskei tussen daardie soorte parallelisme wat verwantskapshepalende waarde besit en dié wat dit nie besit nie.

So moeilik is dit om tussen parallelisme en homologie te onderskei dat, aldus Romer, selfs die student wat intiem met die onderwerp vertroud is gedwing kan word om die moontlikheid toe te gee dat twee diere, so nou verwant soos die gorilla en die sjimpansee, oor die hele afstand vanaf die visstadium op parallelle wyse kon ontstaan het.

llomologie en genetika

Dit is vanselfsprekend dat as homologie gemeenskaplike afstamming impliseer, dit ook genetiese affiniteit moet behels m.a.w. 'n mens sou verwag dat dit deur die oorerwing van identiese gene van geslag tot geslag tot stand kom. Boyden verklaar dan ook met nadruk dat homologie 'n genetiese verskynsel is en dat die meganisme daarvan is die ordelike wisselwerking tussen gene, sitoplasma en omgewing. Die ondersoek na die verband tussen homologie en genetika gaan weliswaar nie verder terug as 1923 nie, en daar kan op hierdie stadium nog nie 'n bevredigende beeld gegee word van die reeks opeenvolgende reaksies wat gedurende die ontwikkeling van enige twee homoloë organe optree nie. Daarby mag veronderstel word dat die finale bewys vir die homologie tussen twee organe gesoek moet word in die allelisme van die betrokke gene. Die toets vir allelisme vereis ongelukkig kruishevrugting en die produksie van minstens een hibriedgenerasie. Aangesien, soos welbekend, sodanige hibriede slegs uit betreklik naverwante organismes verkry kan word, is die trefafstand van hierdie toets te kort om 'n uitspraak te lewer oor die moontlike verwantskappe tussen genera, families ens.

Uit die besprekinge van Boyden (1943) en De Beer $(1938,1958)$ oor die verband tussen homologie en oorerwing kan, al is dit op grond van tot nog toe gebrekkige perspektiewe voorlopig, die volgende afleidings gemaak word.

i) Die spesifieke aard van homoloë organe en trouens van die hele organisme word in die eerste instansie deur oorerwing bepaal.

ii) Een enkele geen kan tegelykertyd meer as een eienskap van die organisme heheer of dit kan beheer oor 'n bepaalde eienskap verloor en heheer oor 'n heeltemal verskillende eienskap verkry. Daarom is eienskappe wat deur identiese gene beheer word nie noodwendig homoloog nie.

iii) 'n Enkele komplekse orgaan kan in sy ontwikkeling deur die wisselwerking van 'n hele aantal gene met mekaar en met die sitoplasma gekondisioneer word. Dit is ook bekend dat een lid van so 'n geengroep met verloop van tyd deur ander vervang 
kan word of selfs verlore kan gaan sonder dat die kenmerk enigsins daardeur verander word. Daarom kan die genetiese verband tussen twee homoloë organe of strukture nie tot individuele gene teruggevoer word nie maar moet dit gebaseer word op die geenkompleks of op 'n groep gene van daardie kompleks.

Hierdie laasgenoemde stelling is te meer waar omdat 'n orgaan nie sy ontstaan te cianke het uitsluitlik aan die gene wat hom beheer nie maar ook aan die proses van induksie, soos reeds uiteengesit, en aan die invloed van die omgewing.

Dit verhaas dus nie dat De Beer $(1958$, p. 153) sy betoog met die volgende stelling afsluit nie: „But the interesting paradox remains that, while continuity of homologous structures implies affinity between organisms in phylogeny, it does not necessarily imply similarity of genetic factors or of ontogenetic processe ia the production of homologous structures".

Ter afsluiting van die bespreking oor die toepasbaarheid van die beginsel van homologie by die verwantskapsbepaling van organismes moet op nog twee bykomende prohleme gewys word.

Homologire en omgewingsinvloede

Dit is wel deur die eksperimente van Sumner (1932) e.a. bewys dat die raskenmerke van diere in die algemeen oorgeërf word en nie in die eerste plek deur die invloed van die omgewing bepaal word nie. Ons weet egter ook dat die organisme kenmerke kan vertoon wat nie op oorerwing berus nie maar as reaksie op omgewingsprikkels tot stand kom. Hierdie kenmerke besit in elk geval geen verwantskapsbepalende waarde nie. Nou is dit baie selde moontlik om van museumeksemplare alleen, d.w.s. van die morfologie, af te lei welke kenmerke deur oorerwing en welke deur omgewingsinvloede in aansyn geroep is.

\section{Homologie en die laer Dierfilums}

Greenberg (1959) wys daarop dat homologie, as 'n filogenetiese argument, dikwels misluk wanneer sulke laagstaande organisasies soos die wat by die Porifera, Coelenterata en Platyhelminthes bestaan, oorweeg word.

\section{Moderne benadering van verwantskapsbepaling}

In die hesef van die ontoereikendheid van morfologiese kenmerke as basis vir klassifikasie en verwantskapsbepaling word daar in die jongste tyd, onder leiding van Huxley (1940), Hennig (1950) e.a. oor 'n veel breër terrein na ooreenkomste en verskille gesoek want, sê Kiriakoff (1959), as die klassifikasie met die evolusie moet ooreenstem dan moet dit gebaseer wees op tyd, ruimte en holomorf wat insluit morfologie, anatomie, embriologie en fisiologie tesame met ekologie, etologie, genetika, biochemie en serologie in soverre hierdie bestaansaspekte hekend is.

Hierdie benadering het tot gevolg gehad dat baie bioloë die sistematiek weer 
tot een van die belangrikste of selfs tot die sentrale biologiese wetenskap wil verhef waarby rekening gehou moet word met alle biologiese subwetenskappe. Tereg wys Lever (1956) daarop dat hierdie sistematiek eintlik nog moet begin want watter dier is serologies, etologies, geografies, paleontologies, vergelykend anatomies, geneties, endokrinologies ens. voldoende ondersoek om 'n definitiewe beeld te kan gee van die kenmerke wat hom tipeer?

Hoewel dit hier in die cerste plek bloot om die klassifikasie gaan, is daar niks wat die filogenetici verhinder om daarin ook verwantskapsbewyse te lees nie. Die hasis van redenasie is soortgelyk aan dié i.v.m. homoloë strukture en word, in die geval van die serologie, soos volg deur Boyden (1958) weergegee: Die teorie van taksonomiese serologie impliseer dat serologiese ooreenkoms afhanklik is van biochemiese ooreenkoms en dat die biochemiese ooreenkoms van proteiene 'n uitdrukking is van die genetiese aard van die organismes wat hulle produseer.

Dit is natuurlik waar dat hierdie benadering homself grotendeels nog deur positiewe resultate moet regverdig as dit nie slegs 'n mooi klinkende teorie moet bly nie. Vergun my dus om enkele van hierdie rigtings, aan die hand van beskikbare resultale, vir u nader toe te lig.

\section{Kruistelingspotensiaal en verwantskap}

Dit is vandag byna algemene kennis dat nie-verwante dierspesies nie onderling vrughaar is nie in die sin dat hulle of glad nie hibriednakomelinge lewer nie of slegs steriele nakomelinge voortbring. Hoewel onderlinge vrugbaarheid byna unaniem as bewys van genetiese verwantskap aanvaar word en daarom as nood. saaklike voorwaarde by die meerderheid van die definisies van wat 'n spesie is, ingesluit word, is hier ook opvallende uitsonderinge.

Ten ecrste kan kruisteling slegs toegepas word op organismes wat geslagtclik voortplant. Voorts is die onvermoë tot voortplanting nie noodwendig aan dic onver. enigbaarheid van die manlike en vroulike geslagselle te wyte nie. Dit kan immers ook dic gevolg wees van geografiese isolasie of, waar twee dierspesies dieselfde habitat bewoon, aan verskille t.o.v. die paringsgedraginge tussen die twee spesies of aan die omstandigheid dat die betrokke diergroepe op verskillende tye voortplantingsvaardig word. Dit is juis hierom dat paringsgedrag en geslagsfisiologie in die jongste tyd so 'n belangrike plek in taksonomiese navorsing inneem. Dit verklaar ook waarom Meyers (1950, 1960) hom so ondubbelsinnig uitspreek teen die gebruik van die kruistelingspotensiaal as 'n spesieskriterium en waarom eksperimentele resultate dikwels nie ' $n$ weergawe van die gebeure in die natuur is nie. Meyers wys daarop dat, in die laboratorium, visse wat selfs aan verskillende ordes behoort hibriedlarwe kan voortbring terwyl morfologies- en gedragsverskillende soorte dikwels selfs vrugbare nakomelinge kan lewer ten spyte daarvan dat hulle in die veld 'n volkome genetiese isolasie handhaaf. 
dat morfologies ononderskeibare diervorme, soos bv. verteenwoordigers van die slakgenus Limax, op grond van hoogs tipiese uiteenlopende paringsgedraginge, wat kruisteling onmoontlik maak, in verskillende groepe ingedeel moet word. Hierdie laasgenoemde voorbeeld is tegelykertyd ook 'n bewys van die waarde van etologie as kriterium vir taksonomie.

Hierdie navorsingsrigting het veral twee nadele. Ten eerste kan dit alleen ondersoek word by lewendige eksemplare in hulle normale habitat of onder toestande wat so na as moontlik met hulle normale habitat identies is. Ten tweede moet hier ook rekening gehou word met die verskynsel van variasie tussen individue en met die verdere omstandigheid dat die organisme hom verskillend gedra onder verskillende omgewingstoestande, en lg. bly nooit konstant nie.

\section{Ekologie}

Die gebruikmaking van ekologiese gegewens vereis meer as net 'n oppervlakkige kennis aangaande die wisselwerking tussen die organisme en sy omgewing. Ons weet bv. dat sommige spesies slegs baie beperkte klimaatskommelinge kan verdra terwyl ander spesies meer adaptief is. Dit is ook waar dat die vermoë van 'n gegewe organisme om uiterstes van besondere omgewingsfaktore te verduur dikwels met stygende ouderdom, met die stadium in die lewensloop of om ander redes verander.

\section{Fisiologie}

In 'n bespreking van die belangrikheid van fisiologiese navorsing in die Dierkunde wys Ewer (1951) aan die hand van verskeie voorbeelde hoe die fisiologie ook in diens van die taksonomie en dus, volgens die argument reeds aangehaal, van verwantskapsbepaling kan staan. Hierdie terrein bied bv. dic voordeel dat, met hehulp van sulke moderne fisies-chemiese tegnieke soos chromatografie, spektraalanalise, elektroforese, radiografie en ander die ooreenkomste en verskille in baie gevalle met groter objektiwiteit bepaal en meer akkuraat gemeet kan word. Bowendien verleen dit toegang tot alle lewende organismes vanaf dic ultramikroskopiese bakterieë tot die soogdiere. Laastens is die fisiologiese kenmerke oor die algemeen minder aan variasies onderhewig as die ander genoemde eienskappe, en daarom word dit as meer betroubaar beskou.

Tereg maan Ewer egter tot versigtigheid want die voorkoms van bv. proteïene van gelykwardige fisiologiese betekenis kan nie altyd as bewys van verwantskap aanvaar word nie. Hierdie waarskuwing word onderstreep deur die geval van die hemoglobiene waarvan die onreëlmatige verspreiding in die diereryk welbekend is.

Dit is voorts aangetoon dat 'n hormoon uit die oogsteel van 'n krap geëkstraheer kan word wat die waterbalans van paddas beïnloed op 'n wyse wat aan die uitwerking van die hormone van die hipofiseagterlob herinner. Hierdie ooreenkoms dui sekerlik nie op 'n verwantskap tussen die Arthropoda en die Vertebrata nie, en 
die situasie herinner aan die strydvraag oor homologie en analogie by die morfologiese strukture.

As die ooreenkomste op die hogenoemde gehiede as bewyse van verwantskap aanvaar moet word, dan moet ons in die laaste instansie maar weer aanvaar dat daardie ooreenkomste deur middel van die oorerwing van identiese gene tot stand kom en dan moet daarop gewys word dat niemand mag aanvaar dat enige besondere vertecnwoordiger van 'n spesie die erflike samestelling van alle verteenwoordigers van daardie spesie weerspieël nie. Dit noodsaak die ondersoek van 'n groot aantal organismes en 'n statistiese analise van die resultate voordat betroubare afleidings aangaande die erflike samestelling van die spesie gemaak kan word. Dit is so 'n geweldige taak dat met veiligheid beweer kan word dat, in die huidige stand van ons kennis, geen ras of spesie in terme van gene gekarakteriseer kan word nie.

\section{Gelykagtigheid en Resentheid van Gemeenskaplike A/stamming}

Selfs al sou toegegee word dat, langs die weë hierho aangedui, verwantskap wel vasgestel kan word, dan nog moet die vraag aangaande die graad van die verwantskap in terme van tyd beantwoord word. Is dit 'n geval van bloedfamilie of moet dit êrens in die ry van voorvaders gesoek word?

Hierdie vraag heantwoord Maslin (1952) as volg: Organismes is gelykagtig in direkte verhouding tot die graad van eendersheid van alle fases van hulle bestaan. Hoe groter die persentasie van gemeenskaplike faktore, hoe nouer is die verwantskap.

Bigelow (1956, 1958) hou 'n ander standpunt hierop na want, so betoog hy, ,.... overall similarity and recency of common ancestry are two separate and distinct phenomena which must be considered separately, not as though one is automatically given by the other".

As aanvaar word dat die interpretasie van dic beskikbare gegewens korrek is, dan moet ook aangeneem word dat daardie veranderinge wat die spesies sedert hulle ecrste ontstaan ondergaan het nie altyd en ook nie by alle diersoorte teen dieselfde tempo verloop het nie. Die geval van die Selakantiede wat tot 1938 slegs as fossielc uit die Karboon bekend was en dus gedurende die afgelope 250,000,000 jaar so min verander het, is welbekend. Hierteenoor is daar die geval van die perd wat gedurende die relatief kort tydperk van minder as $50,000,000$ jaar verander het van 'n klein diertjie so groot soos 'n hond en met vier tone aan sy voorpoot en drie aan sy agterpoot, tot die resente perd wat ons almal ken. Hiervolgens moet dit duidelik wees dat, as twee spesies langsaam verander het hulle gemeenskaplike voorvader, ten spyte van hulle groot ooreenkomste, in terme van tyd, haie ver in die verlede kon geleef het. Die teenoorgestelde is teoreties ook moontlik, $\mathrm{nl}$. dat twee spesies wat baie van mekaar verskil maar vinnig verander het 'n hetreklik resentc gemeenskaplike voorvader kon gehad het.

Daarom verklaar Bigelow dat om op grond slegs van gelykagtigheid, die resentheid van gemeenskaplike oorsprong af te lei sonder enige gegewens aangaande die transformasiesnelhede van die verlede, vergelykbaar is met 'n poging om 
gasdruk slegs van volume te bereken sonder 'n kennis van die temperatuur in of rondom die houer.

\section{Slotopmerking}

Uit die voorafgaande betoog mag nie afgelei word dat gelykagtigheid hocgenaamd nie verwantskap kan aandui nie. Inteendeel. Dit kan in baie gevalle wel 'n aanduiding van verwantskap lewer. In sommige gevalle kan dit met resentheid van oorsprong ooreenstem en in ander gevalle nie. Die tragedie is dat ons oor geen onfeilbare metode beskik waarvolgens die alternatiewe moontlikhede onderskei kan word nie. Wie dit negeer is niks minder as wetenskaplik oneerlik nie. Dit is tot nog toe selfs onmoontlik om gemeenskaplike afstamming eksperimenteel te hewys i1) daardie gevalle waar dit 'n onweerlegbare feit is soos bv. die verwantskap tussen ouer en kind. Ons weet bv. dat homogene veloorplanting by die mens slegs hy identiese tweelinge suksesvol uitgevoer kan word maar nie tussen twee ander kinders van dieselfde ouerpaar of tussen ouer en kind nie. Boonop is, selfs hy identiese tweelinge, die vingerafdrukke nog verskillend van mekaar.

Sowel die taksonoom as die filogenetikus behoort derhalwe altyd in gedagte te hou dat hy slegs met fragmente van die natuur werk sodat sy resultate niks meer as 'n blote benadering tot die werklikheid kan wees nie en soms nie eens dit nie. Buitendien is daar 'n subjekliewe element aanwesig in elke waarneming en in clke heoordeling van gegewens. Terwyl die Christenwetenskaplike hiervan hewus moet wees en voortdurend teen die euwels daarvan moet waak moet hy cgter ook, in die woorde van Lever (1950), gewaarsku wees dat, naas 'n volkome eerbiediging van Gods Woordopenlaring slegs 'n volkome eerbiediging van Gods Naluuropenharing hom kan bewaar van die misstappe van die verlede by daardie gelecnthede toe slic Christendom hom met die kernvrae van die natuurwetenskap ingelaat het.

Met 'n gees van wetenskaplike nederigheid aanvaar ek dat, ten spyte van dio oorweldigende vordering wat in die 102 jaar sedert Darwin op biologiese gebied gemaak is, ons nog maar in die daeraad van die wetenskaplike eeu leef en dat elke nuwe ligstraal die handewerk van 'II almaglige Skepper duideliker blootlê.

Hooggeagte here Lede van die Raad van die Potchefstroomse Universitcit vir Christelike Hoër Onderwys,

$\mathrm{U}$ het my, met dic benoeming tot hoogleraar, tegelykertyd op 'n besondere wyse vereer en 'n groot verantwoordelikheid op my gelê. As my aanvaarding daarvan 'n aanduiding moes wees dat ek myself daarvoor in my cie krag geskik ag dan sou ek dit moes bedank het. Ek waardeer dit dat u my vir hierdie amp waardig genoeg geag het.

Hooggeleerde G. T. S. Eiselen,

U plek in die Departement Dierkunde sal, sover dit myself hetref, nooit gevul kan word nie. $U$ het aan my 'n voorbeeld van onselfsugtige diens gestel wat nic deur my geëwenaar kan word nie maar wat my steeds tot inspirasie sal wees. 
Hooggeleerde Dame en Here Dosente in die Departement Dierkunde, Dames en Here Studente,

Dit is my oortuiging dat die ontplooiing van 'n Universiteitsdepartement nie in die eerste plek van die professor afhanklik is nie mar veelecr van die gemeen. skaplike lydrae van die dosente en studente in daardie Departement. In die gesindheid van my voorganger wil ek dus met u saamwerk aan die nithouing van ons Departement.

Dames en Here, ek dank u vir a vererende teenwoordigheid en vir u vriendelike aandag.

\section{J. A. VAN EEDEN.}

\section{LITERATUURVERWYSINGS}

BIGELOW, R. S. 1956. Monophyletic classification and evolution. Syst. Zool. 5: 145. BIGELOW, R. S. 1958. Classification and phylogeny. Syst. Zool. 7: 49.

BIGELOW, R. S. 1959. Similarity, ancestry and scientific principles. Syst. Zool. 8: 165. BOYDEN, A. 1943. Homology and analogy: A century after the definitions of homologue and analogue of Richard Owen. Quart. Rev. Biol. 18: 228.

"BOYDEN, A. 1947. Homology and analogy. A critical review of the meanings and implications of these concepts in biology. Amer. Midl. Nat. 37: 648.

BOYDEN, A. 1953. Fifty years of systematic serology. Syst. Zool. 2: 19

DARWIN, C. 1859. On the origin of species by means of natural selection, or the preservation of favoured races in the struggle for life. 6th Edition. 1920. New York and London, Appleton.

DE BEER, G. R. 1938. Embryology and evolution in Evolution, essays on aspects of evolutionary biology. p. 57. Edit. by G. R. de Beer. Oxford Clarendon Press, Oxford

DE BEER, G. R. 1958. Embryos and ancestors. Clarendon Press, Oxford.

DICE, L. R. 1952. Quantitative and experimental methods in systematic zoology. Syst Zool. 1: 97.

EWER, D. W. 1951. Physiology and evolution. S. Afr. J. Sci. 48: 115.

*GEGENBAUR, K. 1878. Elements of comparative anatomy. Translated by J. F. Bell. London, Macmillan Co.

GREENBERG, M. J. 1959. Ancestors, embryos and symmetry. Syst. Zool. 8: 212.

*HAECKEL, E. 1866. Generelle Morphologie der Organismen. Berlin, Georg Reimer.

"HENNIG, W. 1950. Grundzuge einer Theorie der phylogenetischen Systematik. Berlin, Deutscher Zentralverlag.

"HUXLEY, J. S. 1932. Problems of relative growth. London.

HUXLEY, J. S. 1945. Evolution, the modern synthesis. New York and London, Harper and Brothers.

KIRIAKOFF, S. G. 1959. Phylogenetic systematics versus typology. Syst. Zool. 8: 117

"LANKESTER, E. R. 1870. On the use of the term homology in modern zoology, and the distinction between homogenetic and homoplastic agreements. Ann. Mag. nat. Hist. 6: 35 .

LEVER, J. 1950. Het soortbegrip en de levende strukturen. Openbare les uitgesproken bij de aanvaarding van het lectoraat in de morphologie aan de Vrije Universiteit te Amsterdam.

LEVER, J. 1956. Creatie en Evolutie. N.V. Gebr. Zomer en Keuning Uitgeversmaatschappij, Wageningen.

MASLIN, T.P. 1952. Morphological criteria of phyletic relationships. Syst. Zool. 1: 49. 
*MEYERS, G. S. 1950. The systematic status of Hyla septentrionalis. Copeia: 203.

MEYERS, G. S. 1960. Some reflections on phylogenetic and typological taxonomy. Syst. Zool. 9: 37.

"OWEN, R. 1843. Lectures on the comparative anatomy and physiology of the Invertebrate animals. London, Longman, Brown, Green, Longmans.

*ROMER, A. S. 1949. Time series and trends in animal evolution. in Genetics, paleontology and evolution. Edit. by G. L. Jepson, E. Mayr, G. G. Simpson. Princeton, Princeton University Press, N.J.

"SUMNER, F. B. 1932. Genetic, distributional and evolutionary studies of the subspecies of deer mice (Peromyscus). Biblio. Genetica 9: 1 .

SZARSKI, H. 1949. The concept of homology in the light of the comparative anatomy of vertebrates. Quart. Rev. Biol. 24: 124

-Oorspronklike publikasies nie ter insae gehad nie. 